\title{
Concept of Water, Land and Energy Productivity in Agriculture and Pathways for Improvement \\ Upadhyaya $A^{*}$ and Alok K Sikka
}

Division of Land and Water Management, Indian Council of Agricultural Research, India

\begin{abstract}
Land and water are finite natural resources, which are diminishing due to indiscriminate and unscrupulous exploitation. Ever increasing population is also posing a challenge to produce more from the available resources. Proper understanding of the concept of land, water and energy productivity has become quite relevant in recent days. The technologies/ strategies in which input application is more precise, efficient and cost effective and output is adequate in quantity, excellent in quantity, well in time and profitable, will lead to enhancement of land, water and energy productivity in agriculture. In this paper, concept of land, water and energy productivity, assessment procedure of crop and agricultural water productivity and case study of Pabnawa minor in Kurukshetra, Haryana (India), have been discussed and various means/ pathways to enhance productivity by employing suitable technologies/strategies have been highlighted.
\end{abstract}

Keywords: Natural resources; Energy productivity; Horticulture; Livestock

\section{Introduction}

Land and water are finite natural resources, which are diminishing due to indiscriminate and unscrupulous exploitation. Due to increasing population pressure, situation becomes more serious and calls for efficient and productive utilization of resources. Share of water diversion for agriculture is projected to reduce in future due to other competing demands. Growing water scarcity as a result of increasing demand is challenging to increase the productivity of land, water and energy to usher in the era of "evergreen revolution". Besides physical availability of water, it is economical accessibility of water with minimum energy input, which is causing concern to get maximum agricultural output or value for every drop of water used in agriculture. Understanding the concept of water, land and energy productivity and its enhancement in groundwater irrigated areas assume yet greater importance where water is either scarce due to faster depletion of water table as in the western IG basin or it is costlier to pump water in eastern part of the IG basin owing to diesel operated pumps.

\section{Concept and definition of water productivity}

Productivity is a ratio between a unit of output and a unit of input. Water productivity is used exclusively to denote the amount or value of product over volume or value of water used or depleted or diverted. Increasing the productivity of water means, in its real sense, getting more benefit from every unit of water used for various production systems. The definition of water productivity is scale dependent. From the farmer's viewpoint, it means getting more production per unit of irrigation water. But, at a river basin scale or at the country level, this means getting more value/benefit per unit of water resource used. Water productivity will depend on many factors other than quantity of water applied. Various factors, which influence water productivity, include cropping pattern, crop variety, level of other inputs applied, management factors etc. Though water is only one of the factors of agricultural production and cannot be meaningfully separated from the others, an estimate of its productivity and knowledge about the factors which influence it will help in making the future plans to improve water productivity in a particular area.

Raising crop water productivity means raising crop yields per unit of water consumed, though with declining crop yield growth globally, the attention has shifted to potential offered by improved management of water resources [1]. It provides a means both to ease water scarcity and to leave more water for other competing demands.

The key to understanding the ways to enhance water productivity is to understand what it means [1]. Water productivity can be analyzed at the plant level, field level, farm level, system level and basin level, and its value would change with the changing scale of analysis. Many researchers have argued that the scope for improving water productivity through water management, or efficiency improvement, is often overestimated and re use of water is under-estimated [2].

Water productivity may be defined as the ratio of the net benefit from crop, forestry, fishery, livestock, and mixed agricultural systems to the amount of water required to produce those benefits. In its broadest sense it reflects the objectives of producing more food, income, livelihoods, and ecological benefits at less social and environmental cost per unit of water used, where water use means either water delivered to a use or depleted by a use. In simple words, it implies growing more food or gaining more benefits with less water. Within the broad definition of water productivity there are interrelated and cascading sets of definitions used for different purposes. Physical water productivity relates the mass of agricultural output to water use- "more crop per drop." Economic water productivity relates the economic benefits obtained per unit of water used and has also been applied to relate water use in agriculture to nutrition, jobs, welfare, and the environment.

Crop water productivity: Crop water productivity denotes the amount or value of product (i.e., crop) over volume or value of water used or depleted or diverted. It varies with location depending on the factors such as cropping pattern, crop genetic material, climatic conditions, irrigation technology, field water management,

*Corresponding author: Upadhyaya A, Division of Land and Water Management Indian Council of Agricultural Research, India, Tel: + 612222 3962; E-mail: aupadhyaya66@gmail.com

Received December 23, 2015; Accepted January 29, 2016; Published February 01,2016

Citation: Upadhyaya A, Alok KS (2016) Concept of Water, Land and Energy Productivity in Agriculture and Pathways for Improvement. Irrigat Drainage Sys Eng 5: 154. doi:10.4172/2168-9768.1000154

Copyright: () 2016 Upadhyaya A, et al. This is an open-access article distributed under the terms of the Creative Commons Attribution License, which permits unrestricted use, distribution, and reproduction in any medium, provided the original author and source are credited. 
infrastructure and on the labour, fertilizer, and machinery inputs as well as economic and policy incentives to produce. In general crop water productivity is a function of water applied, which depends on space scale and generally increases from small plots to large domains at basin scale because applied water is recycled and reused.

Agricultural water productivity: Agricultural water productivity takes into account multiple water uses like agriculture, horticulture, forest, livestock, fisheries, environment etc. It means that if all water users are taken into account and concept of recycling and reuse of water is considered in agricultural production system, then agricultural output per unit of total water input is referred as agricultural water productivity. Since agricultural water productivity assessment considers multiple uses of water, hence its value is higher than the crop water productivity.

Land and energy productivity: On the similar lines, concept of land productivity and energy productivity can also be realized. Basically these terms also indicate about agricultural production per unit of land and per unit of energy. The purpose of defining these terms is to measure the existing performance of these resources and suggest pathways to enhance productivity. Infact, there is a need to study tradeoff among water, land and energy productivity and attempts should be made to improve productivity by efficiently utilizing water, land and energy resources.

\section{Water productivity and water use efficiency}

The classical concept of irrigation efficiency used by water engineers to analyze the "productive use" of water omitted economic values and looked at the actual evapo-transpiration (ET) against the total water diverted for crop production [1]. Over and above, it does not factor in the "scale effect") [3]. Further, classical irrigation efficiency is defined as the crop water requirement (actual evapotranspiration minus effective precipitation) divided by the water withdrawn or diverted from a specific surface-water or groundwater source. 'Losses' in this approach include transpiration and evaporation (evapotranspiration), but also seepage, percolation and runoff, processes in which the water is not consumed. These latter so-called 'losses' may be captured or recycled for use elsewhere in the basin. Thus, classical measures of efficiency tend to underestimate the true efficiency and ignore the important role of surface irrigation systems in recharging groundwater and providing downstream sources of water for agriculture and other ecosystem services.

The notion of water productivity is evolved from two disciplines. Crop physiologists defined 'water use efficiency' as carbon assimilated and crop yield per unit of transpiration, and later as the amount of produce per unit of evapotranspiration. Irrigation specialists have used the term 'water use efficiency' to describe how effectively water is delivered to crops and to indicate the amount of water wasted. But this concept provides only a partial and sometimes misleading view because it does not indicate benefits produced, and water lost by irrigation is often gained by other users. Water productivity analysis can be seen as part of an ecosystem approach to managing water. Rain, natural flows, withdrawals, and evaporation support terrestrial and aquatic ecosystems, which produce numerous services for people. The primary service of agro-ecosystems is food and fiber production, but other important services are produced as well.

\section{Units of expression of water productivity}

Water productivity analysis can be applied to crops, livestock, tree plantation, fisheries, and mixed systems at selected scales-crop or animal, field or farm, irrigation system, and basin or landscape, with interacting ecosystems. The objectives of water productivity analysis range from assessing agricultural production (kilograms of grain per unit of water depleted by a crop on a field) to assessing incremental welfare per unit of water used in the agricultural sector. Because expressions for water productivity differ in each context, it is important to be clear about the agricultural output and input terms used.

As water moves down-stream, a drop may be transpired by a plant, be evaporated from the land, or continue to flow downstream to be used and reused by cities, agriculture, and fisheries to produce some output. Physical Water Productivity is generally expressed in terms of ' $\mathrm{kg} / \mathrm{m}^{3}$ ' or ' $\mathrm{kg} / \mathrm{ha}-\mathrm{cm}$ ' or any other unit of mass of agricultural output per unit volume of water used or depleted, whereas Economic Water Productivity is expressed in terms of ' $\mathrm{Rs} . / \mathrm{m}^{3}$ ' or ' $\mathrm{Rs}$. $/ \mathrm{ha}-\mathrm{cm}^{\prime}$ or ' $\$ / \mathrm{m}^{3}$ or ' $\$ / \mathrm{ha}-\mathrm{cm}$ ' or any other unit of economic benefits obtained per unit of water used or depleted.

\section{Water accounting diagram}

The basic question in water productivity assessment is 'which crop/ which drop' to be considered as numerator and denominator. This is aptly answered by identifying the scale at which we measure water productivity. As we move from one scale to another, the potential utility of some water changes. Basin level and/or irrigation system level water productivity takes into consideration beneficial depletion for multiple uses of water. Here, the problem lies in allocating the water among its multiple uses and users and also taking into account multiple uses of the same quantum of water. The same drop or quantum of water may serve hydropower, urban, fisheries and then agricultural needs before it is ultimately depleted. Water accounting employed to estimate the flows across the boundaries of the domain, provides a means to generalize water use across scales, and to understand the denominator of the water productivity [4]. Analytical framework of water accounting at field and basin scale is shown in Figure 1.

\section{Assessment of water productivity}

Water productivity may be computed during Crop period or whole year considering the production value first from crops only (crop water productivity) and then considering other water users including trees, livestock and fish (agricultural water productivity) in case of multiple uses per unit of water inflow (including rainfall, ground water and canal water) as well as water used (total inflow excluding runoff) in the field, farm, irrigation system, basin and landscape. The accuracy of water productivity assessment depends on water accounting procedures or estimation of water used by various users and water lost in various processes. Water accounting provides a means to generalize about water use across scales, and to better understand the denominator of the water productivity. Water accounting can be applied at all scales of interests, and requires the definition of a domain bounded in three-

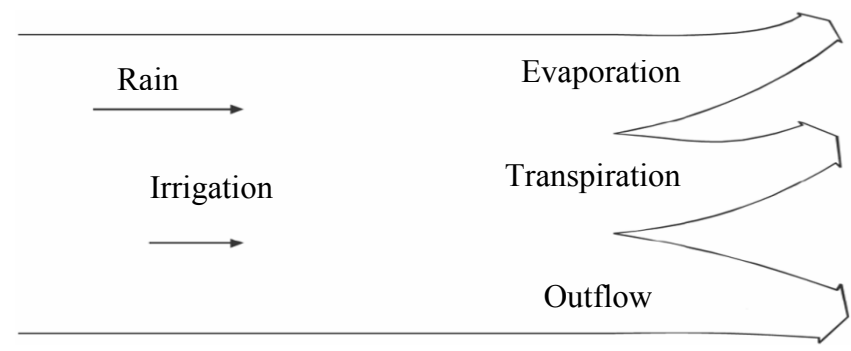

Figure 1a: Inflows and outflows of water in and of the domain at field scale. 


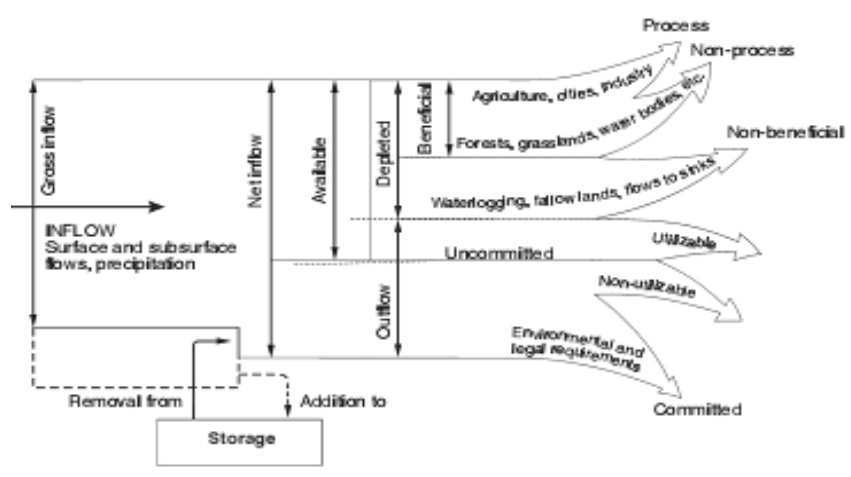

Figure 1b: Generalized water accounting diagram applicable to basin analysis and analysis at other scales.

dimensional space and time. For example, at the field scale, this could be from the top of the plant canopy to the bottom of the root zone, bounded by the edges of the field, over a growing season. The task in water accounting is to estimate the flows across the boundaries of the domain during the specified time period. At the field scale, water enters the domain by rain, by subsurface flows and, when irrigation is available, through irrigation supplies. Water is depleted by the process of growing plants: transpiration and evaporation. The remainder flows out of the domain as surface runoff or subsurface flows or is retained as soil moisture storage. In estimation of water productivity, we are interested in water inflows (rain plus irrigation, or just rainwater in rainfed agriculture) and water depletion (evaporation and transpiration) as shown in Figure 1a.

\section{Case Studies on WP Assessment}

\section{Case study 1}

Most of the water productivity assessments deal with single crop. Sikka et al. discussed the methodology for assessment of water productivity in a multiple use scenario including crops, livestock, fisheries, and forests adopted in the command of RP Channel-V of Patna Main Canal in the Sone Command at Patna and tube well command in Vaishali, Bihar [5]. Crop water productivity was computed considering crops output per unit of irrigation water applied, inflow diverted (including rainfall, ground water and canal water) as well as water used (total inflow excluding runoff), whereas agricultural water productivity was computed considering output of various water users like cereal crops, horticulture, trees, fisheries and livestock. Water productivity was computed during Kharif (Monsoon) and Rabi (Winter) seasons considering the production value first from crops alone and then considering other water users including trees, livestock and fish.

The total water entering the domain (rainfall, canal and tubewell) was calculated for respective command area and the same was incorporated in the SWAP model The water diverted to the command areas of RP Channel-V and tubewell commands in Vaishali was found to be utilized by different crops. SWAP model was used to calculate interception, runoff, evaporation and transpiration separately. The water balance components for both Kharif and Rabi crops were calculated for all the three outlet commands and two tubewell commands.

Finally water productivity was computed considering value from crop production, trees, fish and livestock and water diverted or depleted by various users, as given in Table 1 .
Crop water productivity $\left(\mathrm{Rs} / \mathrm{m}^{3}\right)$ considering applied water varied in the range of 4.79 to 8.39 . Considering water inflow including rainfall, it ranged between 2.42 to 3.11 in the outlet commands. In tubewell commands the crop water productivity for applied water ranged from 14.03 to 29.61 , whereas it was 2.39 to 2.81 in case of total water inflow including rainfall. Agricultural water productivity $\left(\mathrm{Rs} / \mathrm{m}^{3}\right)$ considering applied irrigation water varied in the range of 5.28 to 10.66 . Considering total water inflow including rainfall, it ranged between 2.67 to 3.96 in the outlet commands. In tubewell commands the total water productivity ranged from 18.09 to 38.73 for applied water and 3.09 to 3.68 for total water inflow including rainfall. Lower water productivity considering total water inflow (irrigation + rainfall) in tubewell command may be attributed to higher proportion of rainfall in total water used. The analysis clearly indicates that in canal outlet commands, crop water productivity as well as agricultural water productivity are maximum in outlet 27 followed by outlet 17 . Crop water productivity alone does not depict the actual use of water in the command. Since agricultural water productivity takes account of other water users like trees, fodder, livestock, fish etc., its value is higher and as such it gives the true picture of actual water use and productivity of water.

\section{Case study 2}

Chandra et al. carried out study in Pabnawa Minor of Bhakra Canal System with (Latitude $29^{\circ}-31^{\prime}$ and $30^{\circ}-12^{\prime}$ and longitude $76^{\circ}-10^{\prime}$ and $76^{\circ}-43^{\prime}$ ) in Kurukshetra (Figure 2 and Table 2) Irrigation Circle of North-west India in western IGP [6]. The study area is located in the semi-arid tropics in Haryana with average annual rainfall of 625 $\mathrm{mm}$ (80 percent during June to September). Minimum and maximum temperature varies between $5^{\circ}$ to $25^{\circ} \mathrm{C}$ and $12^{\circ}$ to $44^{\circ} \mathrm{C}$, respectively. Soils are fine coarse in texture varying from sandy loam to clay loam. Many farmers have reclaimed sodic soils using gypsum as an amendment.

In each of the four selected watercourses, 15 farmers' fields were selected for detailed monitoring of water use and crop yields. In the selected fields in PH, PM1 and PT section of the water course, wheat was planted using zero tillage and bed planting techniques. However, wheat crop was planted using conventional tillage practices in the selected fields of PM2 command. Information related with different agricultural and water management practices adapted by farmers in the selected fields, was collected on a specially designed data collection form. Systematic observations were recorded for water use on a daily basis from the selected farmers' fields.

\begin{tabular}{|c|c|c|c|c|c|}
\hline $\begin{array}{c}\text { Water } \\
\text { Productivity } \\
\text { (Rs/m } \mathbf{m}^{\mathbf{3}}\end{array}$ & $\begin{array}{c}\text { Outlet 4 } \\
\text { Head } \\
\text { Reach }\end{array}$ & $\begin{array}{c}\text { Outlet 17 } \\
\text { Middle } \\
\text { Reach }\end{array}$ & $\begin{array}{c}\text { Outlet 27 } \\
\text { Tail } \\
\text { Reach }\end{array}$ & $\begin{array}{c}\text { Tubewell 2 } \\
\text { Land } \\
\text { consolidation }\end{array}$ & $\begin{array}{c}\text { Tubewell 11 } \\
\text { Fragmented } \\
\text { land holding }\end{array}$ \\
\hline Area (ha) & 30.61 & 43.68 & 4.65 & 18.74 & 13.21 \\
\hline $\begin{array}{c}\text { Crop WP per } \\
\text { unit of irrigation } \\
\text { water applied }\end{array}$ & 4.79 & 4.95 & 8.39 & 29.61 & 14.03 \\
\hline $\begin{array}{c}\text { Crop WP per } \\
\text { unit of water } \\
\text { inflow including } \\
\text { rainfall }\end{array}$ & 2.42 & 2.73 & 3.11 & 2.81 & 2.39 \\
\hline $\begin{array}{c}\text { Agricultural } \\
\text { WP per unit of } \\
\text { irrigation water } \\
\text { applied }\end{array}$ & 5.28 & 5.90 & 10.66 & 38.73 & 18.09 \\
\hline $\begin{array}{c}\text { Agricultural WP } \\
\text { per unit of water } \\
\text { inflow including } \\
\text { rainfall }\end{array}$ & 2.67 & 3.25 & 3.96 & 3.68 & 3.09 \\
\hline
\end{tabular}

Table 1: Crop and agricultural water productivity. 

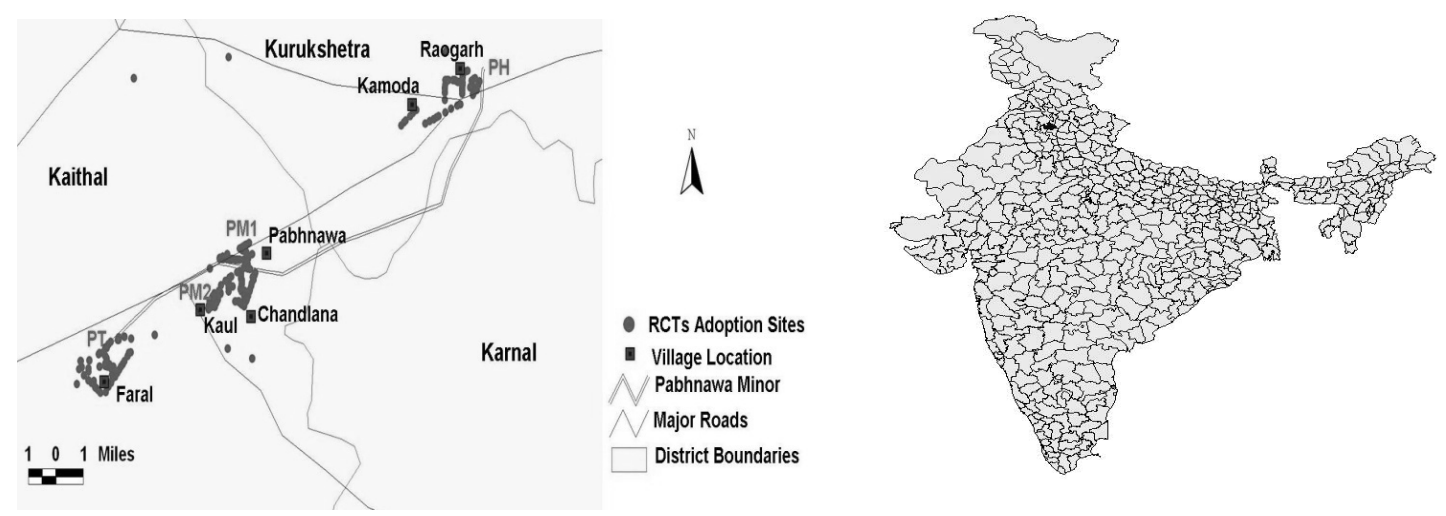

Figure 2: Location of Pabnawa Minor in Kurukshetra where case study was undertaken.

\begin{tabular}{|c|c|c|c|c|c|}
\hline Irrigation Minor & Watercourse & Technology & $\begin{array}{l}\text { Design discharge } \\
\left(\mathrm{m}^{3} / \mathrm{sec}\right)\end{array}$ & $\begin{array}{c}\text { Gross command } \\
\text { area (ha) }\end{array}$ & $\begin{array}{c}\text { Cultivated command } \\
\text { area (ha) }\end{array}$ \\
\hline Pabnawa & Pabnawa Head-end $(\mathrm{PH}) 2820 \mathrm{R}^{\star}$ & Zero Tillage Bed Planting & 0.028 & 231.6 & 208.9 \\
\hline Pabnawa & Pabnawa Middle (PM1) 53705L & $\begin{array}{l}\text { Zero Tillage } \\
\text { Bed Planting }\end{array}$ & 0.041 & 320.2 & 300.0 \\
\hline Pabnawa & Pabnawa Middle (PM2) 53705 R & Conventional Tillage & 0.025 & 341.3 & 169.6 \\
\hline Pabnawa & Pabnawa Tail-end (PT) 80000L & Zero Tillage Bed Planting & 0.052 & 283.0 & 253.4 \\
\hline
\end{tabular}

Letter $L$ and $R$ refer to left and right banks of the water course

Table 2: Details of Selected Watercourses.

The depth of flow at each outlet was measured on a daily basis in each rotation of canal flow. The relationship between measured discharge and depth of flow was worked out for each watercourse. The discharge-depth relationship was used to calculate canal water supplied to farmers' fields after taking into account seepage losses along the watercourse.

The discharge of tube wells owned by the farmers was measured by using the co-ordinate method. Relevant data on irrigation water supplies from the tube wells and canal water, cropping pattern, and yields were collected periodically in the selected fields at each of the four sites. Crop cutting trials were conducted in all the farmers' fields to determine the crop yields. To get realistic estimates of crop yields, a minimum of four crop-cutting trials per plot were conducted. Microplot yields were converted to crop productivity (Kg/ha).

The productivity of water is expressed in terms of $\mathrm{Kg} / \mathrm{m}^{3}$ of water or $\mathrm{Rs} / \mathrm{m}^{3}$ of water. The other terms used here are defined as under:

$$
\text { WP grossinflow }=\frac{(\text { Yield }, \mathrm{kg} / \mathrm{ha})}{\left(\text { Grossinflow }, \mathrm{m}^{3} / \mathrm{ha}\right)}=\frac{(\text { Gross income }, \mathrm{Rs} / \mathrm{ha})}{\left(\text { Grossinflow }, \mathrm{m}^{3} / \mathrm{ha}\right)}
$$

$$
\text { WP irrigation inflow }=\frac{(\text { Yield }, \mathrm{kg} / \mathrm{ha})}{\left(\text { Irrigation inflow, } \mathrm{m}^{3} / \mathrm{ha}\right)}=\frac{(\text { Grossincome, } \mathrm{Rs} / \mathrm{ha})}{\left(\text { Irrigation inflow, } \mathrm{m}^{3} / \mathrm{ha}\right)}
$$

The term gross inflow represents the water from canal, groundwater pumped by the tube wells and rainfall received during crop season. Irrigation inflow includes only the canal water supplies and groundwater abstraction received from tube wells. Thus, the precipitation received in the area is not included in calculating irrigation inflow. level:

The following production indicators were used at the water course

$$
\text { Output }_{\text {grossinflow }}\left(\mathrm{Rs} / \mathrm{m}^{3}\right)=\frac{\text { Gross value of produce }(\mathrm{Rs})}{\text { Gross inflow at watercourse inlet }\left(\mathrm{m}^{3}\right)}
$$

$$
\text { Output }_{\text {grossinflow }}\left(\mathrm{Rs} / \mathrm{m}^{3}\right)=\frac{\text { Gross value of production }(\mathrm{Rs})}{\text { Gross inflow at watercourseinlet }\left(\mathrm{m}^{3}\right)}
$$

Water productivity in both Zero tillage and conventional tillage decreases (Figure 3) as one moves from plot level to watercourse level (i.e for the three level of analysis). This trend is same for all the three reaches of Pabnawa minor. Although absolute value of WP decreases from Plot to Watercourse level, higher percentage level of increase in ZT over CT at the farm and watercourse level (35 \& 37\% as against $20 \%$ at plot level) suggests benefit of ZT in water saving at watercourse level.

Wheat Water productivity in Bed planting method of crop establishment is generally higher than Zero tillage and conventional tillage at Plot level in different reaches. Water productivity of wheat in Bed planting is greater than zero tillage and wheat water productivity in zero tillage is greater than conventional tillage across Plot to Watercourse scales (Figure 4).

The comparison of benefit (gross margin) per unit of water used (consumed) under zero and conventional tillage practices at different locations of the watercourses studied are given in Table 3.

As can be seen from Table 3, the benefit for zero tillage over conventional tillage has increased by a margin of $35 \%$ to $66 \%$ per unit of irrigation water. Water and land Productivity of bed planted Rice and conventional tillage rice is given in Table 4.

Bed planted rice yielded 0.2 to $14 \%$ less yield over conventional tillage (Table 4). The irrigation water productivity for rice under BP is higher (22 to $28 \%$ ) than that of CT but land productivity is lesser as compared to conventional tillage. There is a trade off between water productivity and land productivity in bed planted rice.

Water productivity of Wheat at Farmers' field computed using SWAP model is given in Table 5. 
Citation: Upadhyaya A, Alok KS (2016) Concept of Water, Land and Energy Productivity in Agriculture and Pathways for Improvement. Irrigat Drainage Sys Eng 5: 154. doi:10.4172/2168-9768.1000154

Imigation Water Productivity (kg/m3) in Wheat in Rabi 2002-03

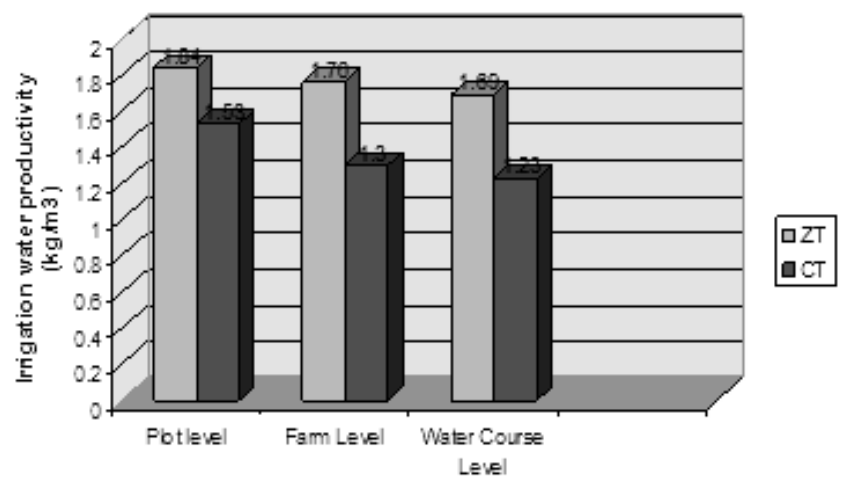

Figure 3: Irrigation water productivity at plot, farm and watercourse level.
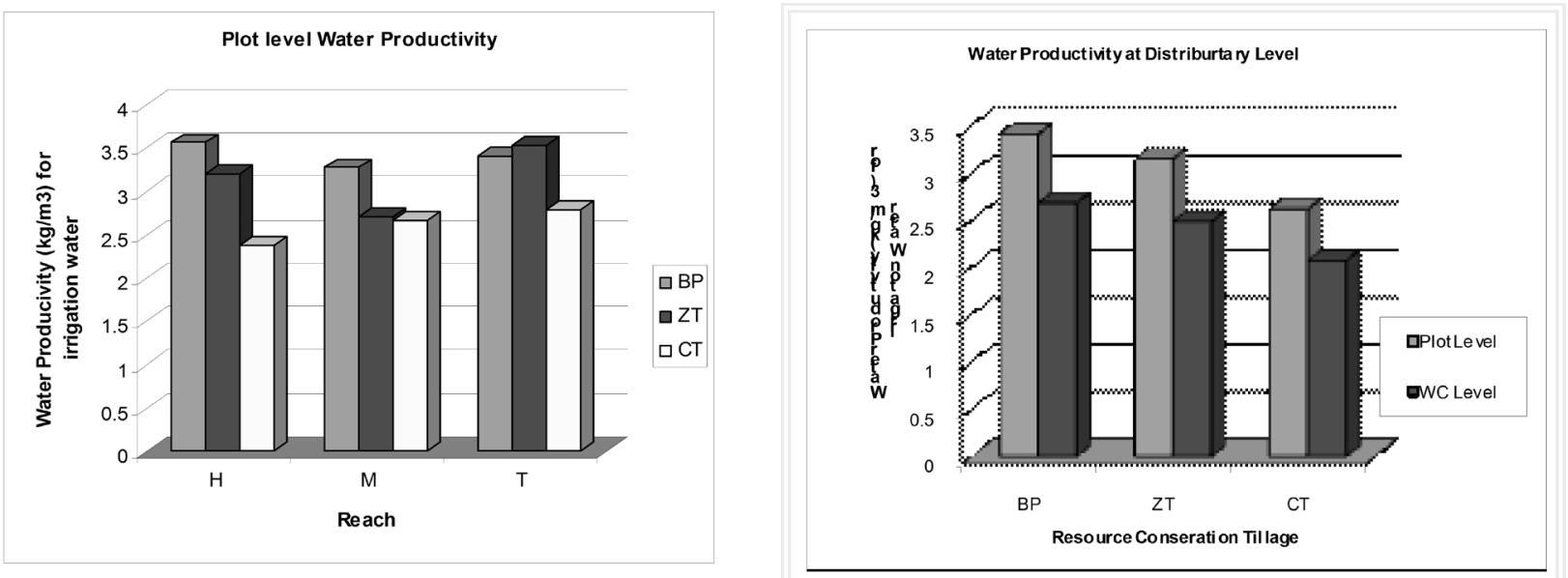

Figure 4: Wheat water productivity at different scales for rcts Pabnawa distributary, Haryana, India.

\begin{tabular}{|c|c|c|c|}
\hline Location & $\begin{array}{l}\text { Tillage } \\
\text { Practice }\end{array}$ & $\begin{array}{c}\text { Benefit } \\
\left(\mathrm{Rs} / \mathrm{m}^{3}\right) \text { of irrigation Water) }\end{array}$ & $\begin{array}{c}\text { Benefit } \\
\text { (Rs } / \mathrm{m}^{3} \text { of gross water) }\end{array}$ \\
\hline Pabnawa Head-end $2820 \mathrm{R}^{*}(\mathrm{PH})$ & Zero tillage & 7.3 & 5.7 \\
\hline Pabnawa Middle 53705L (PM1) & Zero tillage & 5.1 & 4.1 \\
\hline Pabnawa Middle 53705 R (PM2) & Conventional tillage & 3.8 & 3.1 \\
\hline Pabnawa Tail-end, 80000L (PT) & Zero tillage & 5.8 & 4.5 \\
\hline
\end{tabular}

Table 3: Comparison of profitability per unit of water in different tillage practices among different watercourses.

\begin{tabular}{|c|c|c|c|c|c|c|c|}
\hline Location & Method of Sowing & $\begin{array}{l}\text { Average Depth of } \\
\text { Irrigation. Water } \\
\text { (cm) }\end{array}$ & $\begin{array}{l}\text { Average depth of } \\
\text { gross water }(\mathrm{cm})\end{array}$ & $\begin{array}{l}\text { Average Yield ( } t / \\
\text { ha) }\end{array}$ & $\begin{array}{c}\text { Irrigation Water } \\
\text { Productivity } \\
\left(\mathbf{k g} / \mathrm{m}^{3}\right)\end{array}$ & $\begin{array}{c}\text { Gross water } \\
\text { productivity (kg/ } \\
\left.\mathbf{m}^{3}\right)\end{array}$ & $\begin{array}{c}\text { Average Yield } \\
(\mathrm{t} / \mathrm{ha})\end{array}$ \\
\hline $\mathrm{PH}$ & $\mathrm{BP}$ & 124.63 & 130.43 & 4.76 & 0.38 & 0.37 & 4.76 \\
\hline PM1 & $\mathrm{BP}$ & 137.95 & 143.75 & 5.43 & 0.39 & 0.38 & 5.43 \\
\hline PT & $\mathrm{BP}$ & 100.56 & 106.36 & 4.93 & 0.49 & 0.46 & 4.93 \\
\hline PM2 & CT & 175.92 & 181.72 & 5.53 & 0.31 & 0.30 & 5.53 \\
\hline
\end{tabular}

Table 4: Water and land Productivity of bed planted Rice and conventional tillage rice.

It may be observed from Table 5 that WPI under bed planting is higher than that of zero tillage by $25 \%$ and by $79 \%$ compared to conventional tillage. Zero tillage water productivity is higher by $42 \%$ from that of conventional tillage. These results are in conformity with the estimates from observed values.

Results of this analysis indicate the superiority of Zero tillage over the Conventional tillage both in terms of irrigation water productivity and land productivity in wheat besides profitability. Water productivity in both Zero tillage and Conventional tillage decreases as one moves from plot level to watercourse level (i.e. for the three levels of analysis). Higher level of increase in Zero tillage over Conventional tillage at the farm and watercourse level suggests benefits of Zero tillage in water saving at watercourse level. These results are based on limited but rarely 


\begin{tabular}{|c|c|c|c|}
\hline WP Water Productivity $\left(\mathrm{Kg} / \mathrm{m}^{3}\right)$ & BP & ZT & CT \\
\hline $\mathrm{WP}_{\text {, }}$ Water Productivity $\left(\mathrm{Kg} / \mathrm{m}^{3}\right.$ of Irrigation water $)$ & 2.83 & 2.25 & 1.58 \\
\hline $\mathrm{WP}_{\mathrm{T}}$ Water Productivity $\left(\mathrm{Kg} / \mathrm{m}^{3}\right.$ of Transpiration) & 1.71 & 1.50 & 1.28 \\
\hline $\mathrm{WP}_{\mathrm{ET}}$ Water Productivity $\left(\mathrm{Kg} / \mathrm{m}^{3}\right.$ of Evapo-transpiration) & 1.31 & 1.17 & 1.01 \\
\hline $\mathrm{WP}_{\mathrm{G}}$ Water Productivity $\left(\mathrm{Kg} / \mathrm{m}^{3}\right.$ of Rain and Irrigation water $)$ & 1.53 & 1.32 & 1.03 \\
\hline
\end{tabular}

Table 5: Water productivity of Wheat at Rajender's Farm ( 15 ha) with SWAP model.

available field data. While analyzing the data some logical assumptions were made in view of data limitations. The results even if have some limitations but they definitely have suggestive indications of the benefits of adopting resource-conserving technologies at different scales.

\section{Energy Requirement in Drip and Surface Irrigation System}

Srivastava and Upadhyaya determined the size of prime mover and annual energy requirement to cover 5 ha area of sugarcane with drip and surface irrigation system for different water table depths and irrigation requirement [7]. Results are presented graphically in Figures 5 and 6 below.

It is evident from the Figure 5 that the size of prime mover is drastically reduced with adoption of drip irrigation. Similarly Figure 6 shows that contrary to common perception that drip irrigation is more energy intensive, drip irrigation consumes less energy.

\section{Role of Micro-irrigation in Enhancement of Land, Water and Energy Productivity}

Micro irrigation, which broadly includes drip and micro-sprinkler system, is one of the efficient methods of irrigation. Besides improving the quality and quantity of produce, this system helps in saving water even up to $50 \%$ as compared to surface irrigation system. But due to higher cost involvement, this system does not suit to small and fragmented landholders having small purchasing capability. Singh et al. and Singh et al. reported that ICAR-RCER, Patna has developed a Low Energy Water Application (LEWA) device, which can fit on risers and can replace costly sprinklers $[8,9]$. It rotates at very low pressure and sprinkles water over crop like rain. LEWA system can be used to irrigate rice, wheat, vegetables and other close growing crops. The cost of LEWA system is less and it saves water, time and energy. So this is very efficient, effective and beneficial irrigation system for small and marginal farmers having fragmented land holdings (Figure 7). Low Energy Water Application (LEWA) device operates at $0.4-0.6$ $\mathrm{kg} / \mathrm{cm}^{2}$ operating pressure with throw diameter of 6-8 m, application rate $2.6-3.1 \mathrm{~cm} / \mathrm{h}$. The surface uniformity is observed greater than $70 \%$ when operated at an operating pressure of $0.5 \mathrm{Kg} / \mathrm{Cm}^{2}$ or above and sub - surface uniformity is greater than $90 \%$. Basically its discharge is higher than the infiltration rate unlike sprinklers just to keep soil surface wet. With flexible flat hose pipes a LEWA unit for $1000 \mathrm{~m}^{2}$ costs approximately Rs. 15000/- (excluding prime mover). In other words considering 10 shifts its cost is Rs $15000 /$ - per ha whereas cost of sprinkler system is 3-4 times of cost of LEWA system. Singh et al. also discussed the concept and applicability of LEWA and its role in improving water and energy productivity [9].

Water productivity and yield of wheat through LEWA was studied. It was found that there is $45 \%$ and $10 \%$ water saving as well as $50 \%$ and $55 \%$ energy saving over surface and sprinkler irrigation system. Yield values vary as $3.775,3.581$ and 3.525 and Water productivity values as $1.91,1.62$ and $0.95 \mathrm{~kg} / \mathrm{m}^{3}$ in LEWA, sprinkler and surface irrigation system, respectively.

\section{Pathways to Improve Water Productivity}

Pathways to improving water productivity include improving the productivity of green and blue water; improving the water productivity of livestock and fisheries; applying an integrated approach to increase the value per unit of water; and adopting an integrated basin perspective to understand water productivity tradeoffs.

There are many well-known crop per drop improvements. These include more reliable and precise distribution and application of irrigation water, supplemental and deficit irrigation, improved soil fertility, and soil conservation practices. In smallholder livestock

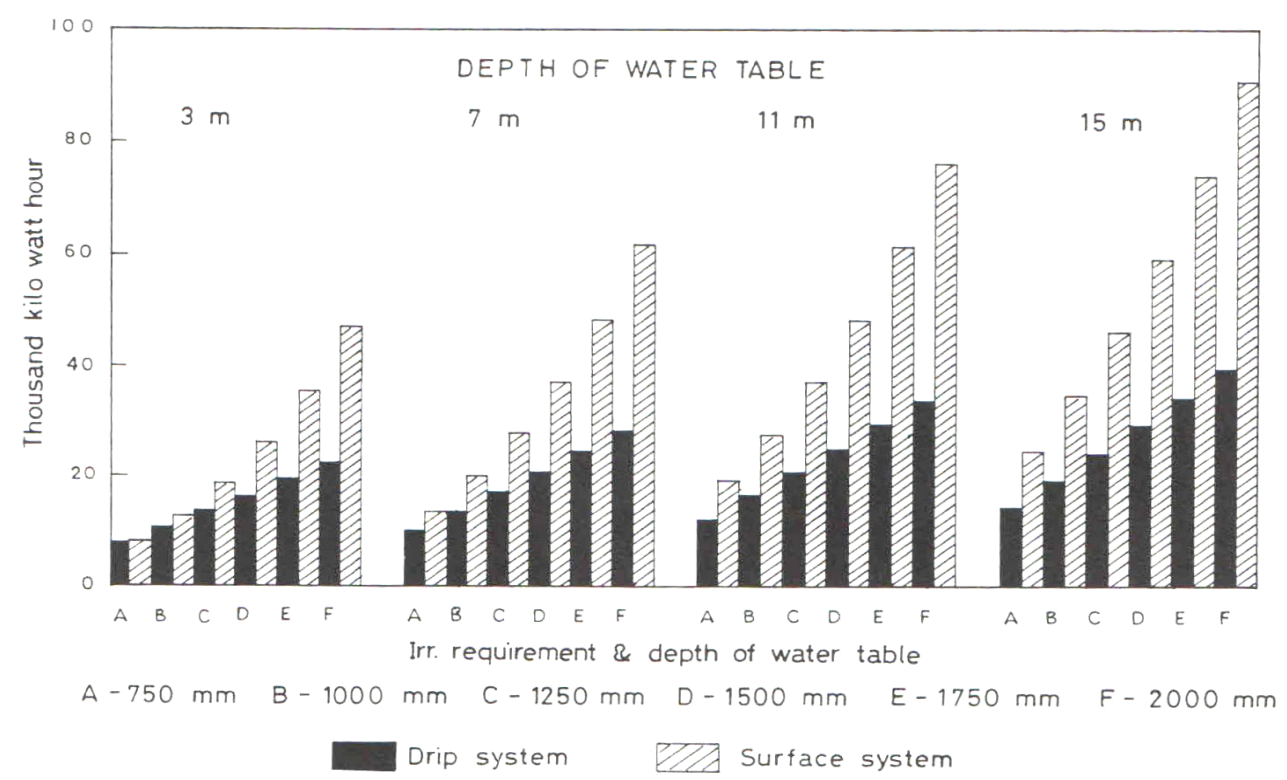

Figure 5: Size of prime mover required for drip and surface irrigation for different water table and irrigation requirement for command area of 5 ha. 
Citation: Upadhyaya A, Alok KS (2016) Concept of Water, Land and Energy Productivity in Agriculture and Pathways for Improvement. Irrigat Drainage Sys Eng 5: 154. doi:10.4172/2168-9768.1000154

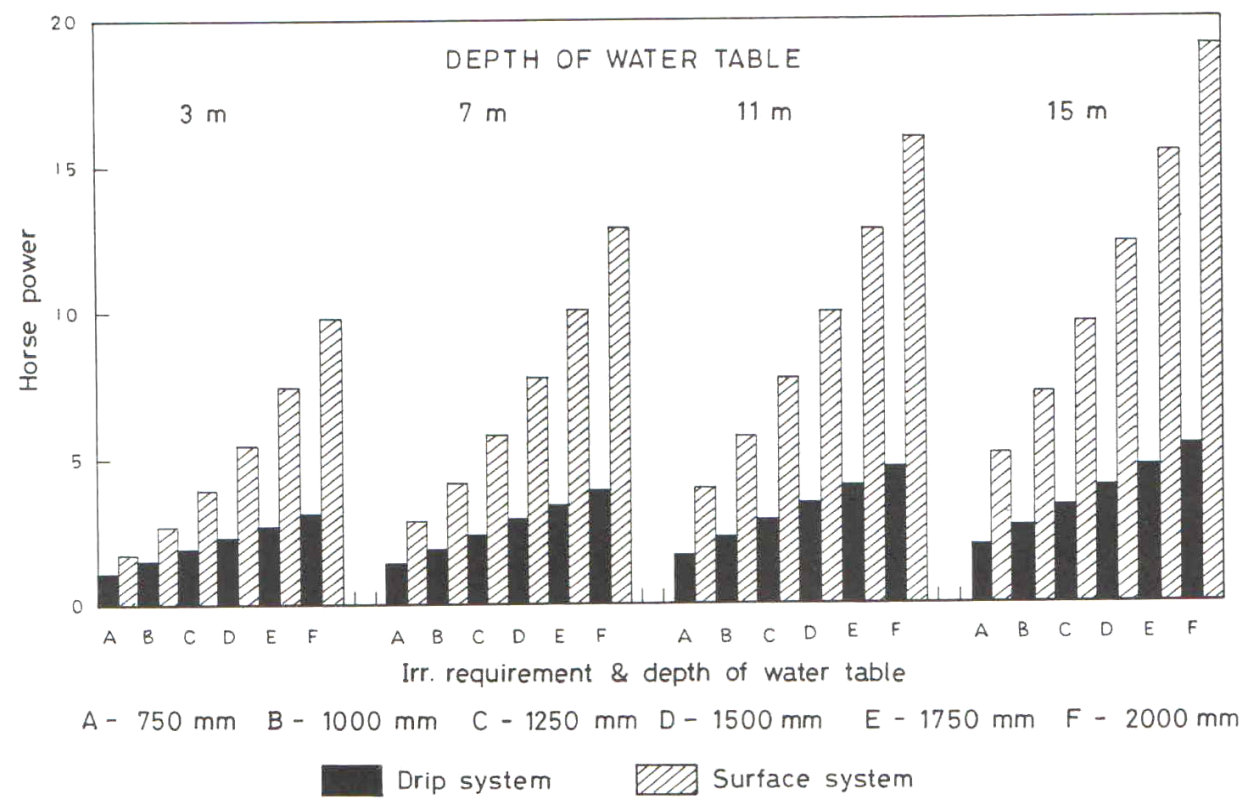

Figure 6: Annual energy consumption for drip and surface irrigation for different water table and irrigation requirement for command area of 5 ha.

\section{Water Productivity and Yield of Wheat in LEWA}

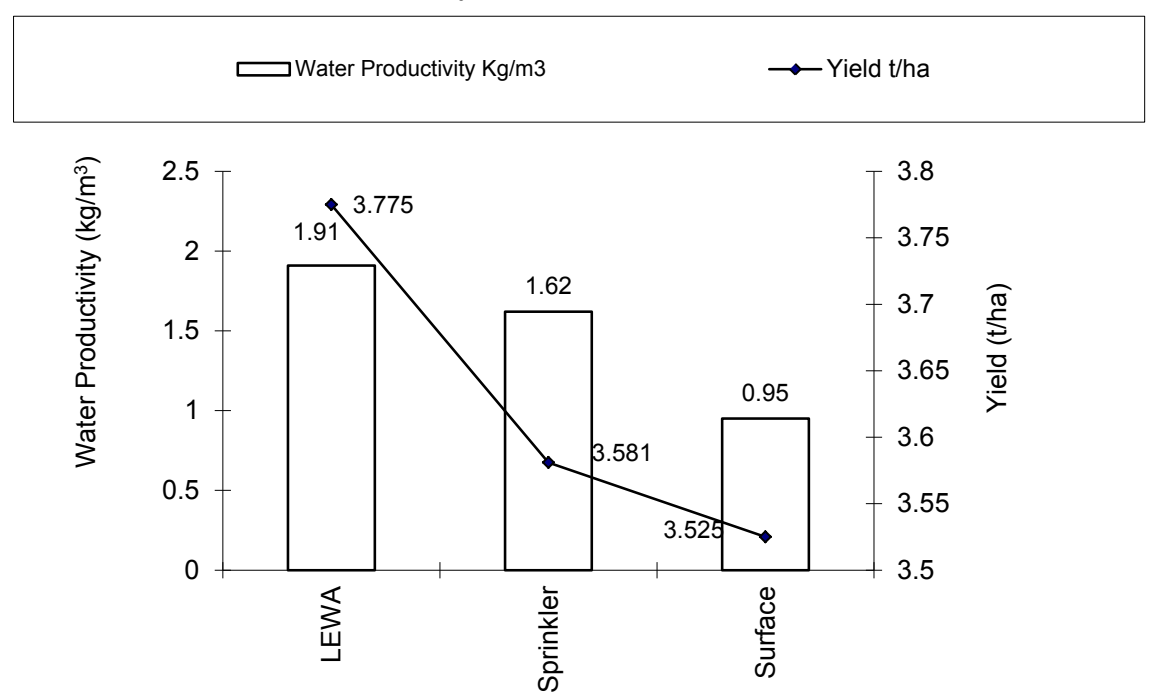

Figure 7: Water productivity and yield of wheat in LEWA sprinkler and surface irrigation methods.

systems, feeding animals crop residues can provide a several fold increase in water productivity. Integrated approaches are more effective than single technologies. Upadhyaya has reported many water saving and water use efficient technologies, which can improve yield, income and livelihood of farmers resulting in enhancement of land and water productivity [10]. Upadhyaya et al. studied spatial and temporal variation of soil moisture under different tillage practices in wheat crop and observed that soil moisture under zero tillage and in furrows of raised bed was found higher than that under conservation tillage and on the beds of raised bed method [11]. Contribution from various activities in enhancing WP is presented below in Table 6.

It shows that $50-60 \%$ improvement in WP is possible through land and water management. Only moderate impacts on crop water productivity can be expected from genetic improvements to plants over the next 15-20 years.

Primary pathways to increase the productivity of water at different scales i.e. Plant, field and basin are as mentioned by Molden et al. are given in Table 7 [12].

Many known technologies and management practices promise considerable gains in water productivity. Achieving those gains requires a policy and institutional environment that aligns the incentives of various users at different scales- from field to basin or country- to encourage the uptake of new techniques and to deal with tradeoffs. It requires policies that: (i) overcome risks, (ii) provide incentives for gains in water productivity, (iii) adjust basin-level water allocation 


\begin{tabular}{|c|c|c|c|}
\hline \multirow{2}{*}{ Product } & $\begin{array}{c}\text { Current Water productivity } \\
\text { (Kg/m3) }\end{array}$ & \multicolumn{2}{|c|}{ Potential contribution to increasing Water productivity } \\
\cline { 2 - 3 } & $0.2-1.5$ & 15 & Water management (\%) \\
\hline Sheat & $0.2-2.4$ & 20 & 40 \\
\hline Cereals & $0.15-0.6$ & 10 & 40 \\
\hline Rice & $0.3-2.0$ & 20 & 45 \\
\hline Maize & $1-20$ & 25 & 15 \\
\hline Trees & $5-20$ & 50 & 15 \\
\hline Vegetables & 10 & 10 \\
\hline
\end{tabular}

Table 6: Contribution from various activities in enhancing WP.

\section{Pathways}

1.Increase marketable yield per unit of water transpired

2. Reducing Outflows (drainage, seepage and percolation) and non-productive depletions (evaporation from soil and water, weeds)

3.Increasing non-irrigation inflows (Rainfall, stored water, marginal quality water, waterlogged/ drainage water)

4.Increasing the effective use of water from the storage

5. Using not yet committed flows

6.Reallocating and co-managing water (multiple use) among uses

Table 7: Pathways to improve water productivity at different levels.

policies, (iv) target the poor with sustainable, water productivity enhancing practices, and (v) look for the opportunities outside the water sector.

High priorities for water productivity improvement include:

- Areas where poverty is high and water productivity low, where the poor could benefit.

- Areas of physical water scarcity where there is intense competition for water.

- Areas with little water resources development.

- Areas of water-driven ecosystem degradation, such as falling groundwater tables and drying rivers.

\section{Other Energy Saving Interventions}

Considerable savings in energy requirement can be made if the level of efficiency of the pumping set is maintained at the minimum expected efficiency of 50 percent. In a survey of irrigation pump sets owned by the farmers in the Nainital Tarai region the average efficiency was found as $36 \%$. The survey indicated that the possible reasons of low efficiency of installed pumping sets are: (i) The pumps are not selected according to the well conditions. (ii) The drive units are not matching the pump requirement. (iii) Improper sizing and excessive length of suction and delivery pipes and $90^{\circ}$ bends are being used. (iv) Standard and good quality foot valve and pipe fittings are not being used. (v) Adequate technical service on the purchase, selection of a pump and drive unit matching with well conditions, installation, operation and maintenance of pumping sets is not available to the farmers.

Various factors influencing the energy requirement in irrigation indicate that by improvements in irrigation management practices irrigation saving can be done. The Potential energy saving in terms of percentage was given as below.

$$
P E S=100\left[1-\left(\frac{D_{n 2} E_{i 1} R_{1} H_{2}}{D_{n 1} E_{i 2} R_{2} H_{1}}\right)\right]
$$

where the subscript 1 indicates initial values and the subscript 2 indicates values after modifications. $\mathrm{D}_{\mathrm{n}}$ is the net amount of irrigation water applied $(\mathrm{mm}) ; \mathrm{E}_{\mathrm{i}}$ is irrigation efficiency, or fraction of pumped water that is stored in the crop root zone; $\mathrm{R}$ is performance rating of pumping plant; and $\mathrm{H}$ is total head required. The equation indicates that following modifications will reduce the pumping energy requirement: (i) reduction of net depth of irrigation $\left(D_{n 2} / D_{n 1}<1\right)$; (ii) reduction in total head $\left(\mathrm{H}_{2} / \mathrm{H}_{1}<1\right)$ or lower pressure requirements; (iii) improved performance rating of pumping plants by adjustment $\left(\mathrm{R}_{1} / \mathrm{R}_{2}<1\right)$; and (iv) increased irrigation efficiencies $\left(\mathrm{E}_{\mathrm{i} 1} / \mathrm{E}_{\mathrm{i} 2}<1\right)$.

In addition to the energy savings as calculated by above equation, three other possible cost and energy saving areas related to irrigation include (i) off-peak irrigation scheduling to reduce peak electrical demands, (ii) reduction of nitrogen losses through reduction of deep percolation losses, and (iii) reduced tillage practices.

Reduction in total water pumped can be achieved through either improvement in irrigation efficiency or reductions in net irrigation applications. Improvements in the application efficiency will reduce the gross water application and thereby reduce the total energy required to pump the water. The amount of water that must be pumped depends on the irrigation system type and the particular irrigation water management practices. It was found that the irrigation efficiency depended more on management than the type of system and he further noted that relatively "poor" systems under proper management were more efficient than "better systems" which were poorly managed.

The installation of runoff reuse systems can provide significant energy conservation to surface irrigators. Reuse systems require additional energy expenditures, however this additional requirement is usually small compared to the energy required to pump the water from the initial source.

Some irrigation systems may only need improved management (adjusting stream sizes, changing length of run, and/or timings) to obtain better efficiency. Land levelling may be needed on some fields before the desired efficiency can be obtained. Surge irrigation may be used to improve graded furrow irrigation. Sprinkler systems may require replacement of nozzles to match the site, reduced lateral spacings and changes in irrigation set times. Trickle irrigation systems may require cleaning or replacement of emitters to improve performance. Most of the irrigation systems can achieve improved efficiency through more intensive management and maintenance. This includes close supervision of the operation of the system and irrigation scheduling to prevent application of excess water. 
Additional savings of water and energy are possible by inducing some moisture stress during part or all of the growing season by limiting irrigation. This procedure may result in reduced yield, thus economic constraints will govern the application of these practices in the field. It is usually possible to select an efficient scheduling process to produce the maximum yield for the attainable level of water use.

In future, farmers may shift to crops requiring less water because of reduced water supplies and/or increased energy costs. This change in cropping pattern will depend upon: the production function of the respective crops, the water supply policy, the type of irrigation equipment, the profitability of the respective crops, alternative energy sources and their costs, and governmental policies.

Reductions in total pumping head can be achieved by (i) reduced pressure sprinkler systems, (ii) substitution of surface water for ground water, (iii) pipeline modifications to reduce friction losses, and (iv) design changes in irrigation wells to reduce head losses.

A study indicated that well development procedures can reduce water table drawdown as much as $50 \%$ for wells constructed using bentonite drilling fluid. The amount of energy savings depends upon the initial well drilling method, construction materials and practices, and aquifer characteristics, all of which can affect the resulting drawdown.

Whenever long pipelines are needed to move water from the source to the field, pumping energy is required to overcome the frictional losses. The amount of friction loss is dependent on the type of pipe, its diameter and length of pipeline. Normally pipe length is fixed, and only the size of the pipe line can be increased or type of the pipeline changed to reduce pumping head, but it will increase the fixed cost. So selection of appropriate size pipeline distribution system depends on energy and cost considerations.

Reducing the pressure of sprinkler systems is a viable method to save energy. Conversion of conventional high pressure sprinkler systems to reduced pressure systems may require redesigning at additional expense. In all the cases, the energy savings resulting from reduced pressure will have to be greater than the cost of additional equipment and extra labour required for more frequent moves of the system.

Energy conservation through improved irrigation management is not limited to the energy used to pump water. Large quantities of energy are used to manufacture fertilizer, primarily nitrogen, which is used in irrigated agriculture. Over irrigation, especially on sandy soils, can leach nitrate nitrogen below the crop root zone, resulting in nitrate build up in the ground water, nitrogen deficiencies in the crop and decreased yields. Several investigators have found nitrate nitrogen loss ranging between 2.5 and $10.2 \mathrm{~kg} / \mathrm{ha}$ per centimeter of deep percolation on sandy soils under surface irrigation systems. It was concluded that nitrate loss through percolation could be minimized by proper selection of the nitrogen amount, nitrogen source and irrigation management. Between 25 and $60 \mathrm{~kg} / \mathrm{ha}$ of nitrate nitrogen can be saved with improved water-nitrogen management procedures. Approximately $1 \mathrm{kWh}$ of electrical energy are required to produce $1 \mathrm{~kg}$ of nitrogen fertilizer in the anhydrous ammonia form. Thus, the annual energy requirements for nitrogen use in irrigation could be reduced by 25 to $60 \mathrm{kWh} /$ ha of electricity.

Reduced tillage can be used to reduce the energy required in irrigation, but perhaps more important than the energy saved is the increased surface water storage capacity created by certain reduced tillage practices. Tillage systems that maintain plant residues on the soil surface protect soil from erosion, increase surface water storage, and improve infiltration by reducing the surface soil sealing caused by rain and irrigation drop impact. Such reduced tillage systems may allow the use of reduced-pressure irrigation systems on low-intake soils, thereby further reducing irrigation energy requirements. Reduced tillage systems will increase surface residues throughout the spring operations. Residues generally retard soil drying and temperature increases, thus delaying planting. Increased surface residue increases demand for proper management and the tillage system should not preclude, but rather complement, other good conservation practices.

Several irrigation management procedures for reducing energy use in irrigation have been presented. These energy saving techniques can be used to ensure continued high level production in spite of energy shortages, production cost increases, and limited water supplies. The improved management of existing irrigation systems help to conserve both energy and water. Pump irrigators in the future may have to accept soil water deficits and the corresponding yield reductions in some years because of limited energy supplies, scheduled electrical power interruptions, or water allocation. Improved management of the irrigation system will help minimize these losses.

\section{Conclusion}

Land and water are two finite natural resources, which are essentially required for agricultural production. To feed ever increasing population of our country, enhancement in production from diminishing resources is the need of hour. Agricultural productivity can be enhanced if land and water resources are utilized efficiently, timely and judiciously and energy is channelized properly in the positive direction. The case studies conducted in the head, middle and tail reaches of RP Channel $\mathrm{V}$ under Patna Main canal in the Sone Command and two tube well commands in Vaishali, Bihar show that agricultural water productivity (considering rain and irrigation water) varied in increasing order from 2.67 to $3.96 \mathrm{Rs} / \mathrm{m}^{3}$ from Head to tail reach and 3.68 and $3.09 \mathrm{Rs} / \mathrm{m}^{3}$ in tubewell 2 with land consolidation and tubewell 11 with fragmented land holdings. Similarly case study 2 in Pabnawa minor showed that wheat water productivity under bed planting was higher than that of zero tillage by $25 \%$ and by $79 \%$ compared to conventional tillage and zero tillage water productivity was higher by $42 \%$ from that of conventional tillage. It was also observed that contrary to common perception, drip irrigation was more energy efficient, since it required less energy than the surface irrigation. It is concluded that adoption of an integrated approach, which takes into account soil-water-crop-climate-humanlivestock resources management and farm mechanization, planning and implementation of location specific, cost effective, energy efficient, simple, sound, sustainable, socially acceptable, and environmentally harmless technologies/ interventions/strategies are the pathways to enhance land water and energy productivity.

\section{References}

1. Kijne J, Barker R, Molden D (2003) Improving Water Productivity in Agriculture Editors' Overview. International Water Management Institute.

2. Seckler D, Molden D, Sakthivadivel R (2003) The Concept of Efficiency in Water Resources Management. International Water Management Institute.

3. Keller A, Keller J, Seckler D (1996) Integrated Water Resources Systems: Theory and Policy Implications. International irrigation Management Institute.

4. Molden DJ, Sakthivadivel R, Christopher JP, Charlotte de F, Klozen WH (1998) Indicators for comparing performance of irrigated agricultural systems. International irrigation Management Institute.

5. Sikka AK, Abdul Haris A, Upadhyaya A, Thakur A, Reddy AR, et al. (2008) Water productivity assessment in the Canal and Tubewell Commands of Bihar-A Case Study. 
Citation: Upadhyaya A, Alok KS (2016) Concept of Water, Land and Energy Productivity in Agriculture and Pathways for Improvement. Irrigat Drainage Sys Eng 5: 154. doi:10.4172/2168-9768.1000154

6. Chandra R, Gupta RK, Sikka AK, Upadhyaya A, Shakthivadivel R (2007) Impact of conservation technologies on water use and water productivity in Pabnawa minor of Bhakra canal system. Rice-Wheat Consortium.

7. Srivastava RC, Upadhyaya A (1998) Study on feasibility of drip irrigation in shallow ground water zones of eastern India. Agricultural Water Management 36: 71-83.

8. Singh AK, Sharma SP, Upadhyaya A, Rahman A, Sikka AK (2010) Performance of low energy water application device. Water Resources Management 24: 1353-1362.

9. Singh AK, Islam A, Singh SR, Upadhyaya A, Rahman A, et al. (2015) Low
Energy Water Application (LEWA) device: Concept and applications. Journal of Soil \& Water Conservation 14: 344-351.

10. Upadhyaya A (2015) Water management technologies in agriculture: Challenges and opportunities. Journal of Agrisearch 2: 7-13.

11. Upadhyaya A, Singh SS, Prasad LK, Roy MK (2015) Spatial and Tempora Variation of Soil Moisture under different Tillage Practices in Wheat Crop. Journal of Agrisearch 2: 175-178.

12. Molden D, Oweis TY, Pasquale S, Kijne JW, Hanjra MA, et al. (2007) Pathways for increasing agricultural water productivity. International Water Management Institute. 